\title{
MODELING THE EQUILIBRIUM PRICE OF THE COMPANIES LISTED IN THE PRAGUE STOCK EXCHANGE
}

\author{
Florin Aliuํ, Adriana Knapkova², Hoang Khang Tran², Bashkim Nurboja ${ }^{1}$ \\ ${ }^{1}$ University for Business and Technology, Lagjja Kalabria, 10000 Prishtine, Kosovo \\ 2 Department of Finance and Accounting, Faculty of Management and Economics, Tomas Bata University in Zlín, \\ nám. T. G. Masaryka 5555, 76001 Zlín, Czech Republic
}

Link to this article: https://doi.org/10.11118/actaun202068040731

Received: 27. 4. 2020, Accepted: 18. 7. 2020

To cite this article: ALIU FLORIN, KNAPKOVA ADRIANA, TRAN HOANG KHANG, NURBOJA BASHKIM. 2020. Modeling the Equilibrium Price of the Companies Listed in the Prague Stock Exchange. Acta Universitatis Agriculturae et Silviculturae Mendelianae Brunensis, 68(4): 731-739.

\begin{abstract}
Valuation provides proper evidence on the financial situation of the firms. Incorrect valuation delivers wrong signals for the market participants and stands on the concepts of markets with information asymmetry. The study measures the estimated intrinsic value of the selected companies listed in the Prague Stock Exchange. Moreover, the results of the work observe influencing factors that deviate stock prices of the companies listed in the Prague Stock Exchange (PSE) from their estimated intrinsic value. Valuation techniques and Monte Carlo Simulation were employed to detain the estimated intrinsic of the selected companies from the Prague Stock Exchange. The estimated results indicate that Czech listed companies deviate from the intrinsic value in the range of 58\% while international companies in the range of 301\%. However, the average deviation within market prices and intrinsic value of the companies listed in the PSE was 179\%.
\end{abstract}

Keywords: valuation, stock prices, equilibrium price, fundamental value

\section{INTRODUCTION}

Valuation is a crucial element that identifies the fundamental performance of the companies. Intrinsic value delivers price signals for the market participants on the existing financial position of the businesses. In contrast, the book value of the company shows differences between assets and debts based on their historical registration. Financial statements stand on the traditional limitations which do not represent the prospect of the firms. Moreover, balance sheets and income statements are based on the records which are irrelevant to the market value of the companies. Company value depends on the two inputs that are negative linked, such as risk and returns. Returns are obtained from the possible future cash flows while company risk stands for the discount rate
(Damodaran, 2012). Besides, increase in the risk level lowers the company value and the other way around. Scholars apply diverse methods on determining the company value. However, the valuation of firms was permanently considered by researchers and practitioners as imprecise science. The valuation process is comprised from numerous assumptions that make the models to a certain extent inaccurate. Company value is imposed on several uncertainties associated with the valuation process. However, uncertainties linked with the valuation steps are mainly considered as errors.

Company value closely associates with the market prices even though market prices are determined from market forces. Stock prices are the only reliable signal that reveals the market position of the companies. Fama (1968) shows that 
in the long-run stock prices constantly tend toward equilibrium (intrinsic value) while are prone to the short-run variations. The profound concept that stock prices tend toward their equilibrium is controversial. The study by Shiller (2000) confirms that stock prices are always lying on the speculative components, driven mainly from the psychological reasons. The financial crisis of 2008-2009 indicated that stock prices do not permanently reflect their fundamental value and are likely to generate asset bubbles. Stock prices that are not close to their intrinsic value carry on misleading indications for the financial investors.

Prices are an essential indicator of allocating financial recourses efficiently. Stock prices reflect expectations for future outcomes rather than present state of the businesses. Stock markets are established under different structures from the commodity markets. Moreover, stock market prices indicate an expectation for the potential cash flows of the firms. Efficient market hypothesis $(\mathrm{EMH})$ indicates that stock prices contain complete information, within and outside of the national economy. Fama (1970) confirm that within efficient markets, stock price experiences a random walk where past prices cannot predict future changes. The efficiency of the stock market improves market confidence where prices do not carry speculative elements. Stock markets of the eastern European countries are characterized by low efficiency and a small number of listed companies. The study by Dragotă and Ţilică (2014) indicate weak efficiency level imposed on the stock markets of the eastern European countries. Guidi et al. (2011) confirm that stock markets of the Central Eastern European countries do not follow a random walk. In addition, their study claim that investors can generate abnormal returns via analyzing historical stock prices. Also, Stoica and Diaconasu (2011) studied the efficiency level of the eastern stock markets from 2000 till 2010 and confirmed weak efficiency linked with their stock prices. Previous studies on the efficiency level of the eastern stock markets show that stock prices in these countries are characterized by speculative elements and do not represent their intrinsic value (equilibrium price). The inefficiency level imposed on the Prague Stock Exchange (PSE) indicates that stock prices diverge from the intrinsic value. Standing on the identified problem, the study estimates intrinsic values of the companies listed in the PSE, not their stock market prices. To the best knowledge it is the only work that determines the financial position of listed companies based on the valuation techniques. Results of the work provide evidence for the investors not solely if the stock prices are overvalued or undervalues but also indicate which are the factors that deviate stock prices from their intrinsic value. Previous studies were mainly focused on the factors that influence stock price movements in the PSE. The following research questions were asked based on the identified research gap:

Q1: What is the intrinsic value of the companies listed in the PSE and their market prices?

Q2: Which are the factors that deviate prices from the estimated intrinsic value to the market prices?

\section{Theoritical Background}

Stock price equilibrium is achieved via the intersection between demand and supply for stocks. Demand for stocks is driven from the internal performance of the firms and macroeconomic outlook of the country. However, supply for stock is linked with present market prices of firms and the need for additional funds. Price equilibrium is considered a core mechanism of the market economy and provides signals for the market participants. However, different elements influence stock price movements. Stock prices might fail to reach equilibrium (intrinsic value) if complete information is not involved in the price change. However, stock markets in the eastern European countries are not the key source for providing liquidity in the economy.

Prague Stock Exchange (PSE) holds a small share within the total financial system of the Czech Republic (CNB, 2018). Pražák and Stavárek (2017) investigated the influence of macroeconomic elements on the stock prices of Visegrad countries. Their study indicates that in the case of Czech Republic, unemployment rate and GDP hold positive effect on the stock prices. Hanousek and Filer (2000) shows that price movements on the PSE are disconnected with the financial and economic prospect of the Czech economy. In addition, their study confirms that stock prices in the PSE do not interfere with macroeconomic fundamentals of the country which indicates that price changes do not represent the economic and financial reality. The exchange rate influences stock prices since most of the listed companies in the PSE are multinational in scale. The work by Grambovas (2003) claims that the exchange rate (DEM/CZK) have a shortrun influence on the PSE while no long-run impact is detected. Economic and financial integration was intensified when the Czech Republic joined the European Union (EU) in 2004. Membership into the EU allowed Eastern European Countries to enjoy quick expansion in their equity markets (Wolff, 2007). Moore and Wang (2007) show that stock markets of Slovakia, Czech Republic, Hungary, Poland, and Slovenia gained higher stability by joining the EU.

Macroeconomic factors play a crucial role in the stock price equilibrium. Economic growth promotes enthusiasm for the entire economy while indicating the dynamism of the economy. Higher GDP stimulates higher demand for stocks and increase stock prices. Previous studies show that inflation dampens real returns on the stock 
investments and negatively influences stock prices. Horobet and Dimitrescu (2009) show that inflation measured through CPI positively affect stock prices in the PSE while exchange rate reveals a negative effect. However, Kulhánek (2012) investigated the relationship within stock prices, money supply and economic growth on the Czech, Polish, Hungarian and Slovak stock markets. The results of the study from 1995 till 2012 represent long-run cointegration within GDP, money supply and stock prices. Interest rates imposed from the central banks' influence the performance of the economy and the demand for stocks. Stoica et al. (2014) investigated the influence of the domestic and global interest rate changes on the stock prices of the eastern European countries. Results of the work obtained from the Vector Error Correction Model found that international interest rates significantly influence stock prices in Romania, Poland, Hungary and Czech Republic. Besides, interest rates enforced from Czech Central Bank, Federal Reserve in the US and German Central Bank have a significant effect on the PSE price changes (Samitas and Kenourgios, 2007). Firm specific factors are an important force in driving stock prices and investors' confidence. However, to the best knowledge there is no study for the Visegrad equity markets concerning the influence of firm performance on the stock prices.

The financial crisis of 2008-2009 confirmed that equity markets are highly integrated. Moreover, the crisis confirmed that financial problems in one country are easily spread on the other countries. Hanousek and Novotny (2013) investigated that the bankruptcy of the Lehman Brothers in 2009 had short run effect on the stock prices in the PSE. US stock markets hold a crucial influence in the world financial system. Gilmore and McManus (2002) on their study from 1995 till 2001, perceived shortterm and long-term co-integration between US equity markets and equity markets in the eastern European countries (Czech Republic, Hungary and Poland). The study conducted by Scheicher (2001) found that Polish and Hungarian stock markets are highly integrated while no signs of integration with Czech stock market. Prior studies confirm that PSE shows short-run integration with western stock markets while in the long run follows its own path. In contrast, our work intends to investigate the deviation within stock prices and intrinsic value of the companies listed in the PSE.

\section{MATERIALS AND METHODS}

The study estimates intrinsic value of the companies listed in the PSE. Discounted Cash Flow Method (DCF) was used to identify the estimated intrinsic value of the selected companies in the PSE. DCF is valuation technique used to identify present value of the firms, standing on the projections for the future cash flows. However, weighted average cost of capital (WACC) stands as discount rate which reflects internal and external risks of the listed firms. Cost of equity has been measured through Capital Asset Pricing Model (CAPM). CAPM is widely used model for pricing financial securities. WACC and CAPM has been adjusted for the company and country risk profile (in our work correction have been done for the Czech Republic). Audited financial statements from the companies listed on the PSE were used to generate the inputs for the valuation process. Annual financial statements were used from 2012 till 2017 in order to obtain WACC and CAPM.

The following formula represents discounted cash flow of the firm

$$
D C F=\sum_{t=1}^{\infty} \frac{C F_{t}}{(1+w a C C)^{t}} .
$$

DCF stands for the discounted cash flow of the firm, CF indicates Free Cash Flow of the Firms (FCFF) and WACC stands for the weighted average cost of capital. FCFF was calculated from the annual financial statements of each firms. WACC was calculated from cost of equity (CAPM) and cost of debt (cd). Cost of debt was calculated from the average interest rate (interest expenses) times percentage of debt on the total structure of the firms. Cost of equity was measured through Capital Asset Pricing Model (CAPM).

$C A P M=R F R+\beta(R F R-R M)$.

RFR indicates risk free rate which was obtain from the long-term Czech government bonds. $\beta$-stands for the beta coefficient which was obtained by regressing company stock returns with PSE returns. $R M$ holds for the market returns that was generated from the PSE yearly returns. Fig. 1 shows input parameters used during the valuation process of the selected firms from the PSE. Indicators such as WACC, CAPM, FCFF and Cd are adjusted for the firm characteristics. Growth rate as the only parameter that is simulated in the model, is obtained from the Damodaran Database.

Fig. 2 shows the schematic diagram of the research work. The study stands on the two main objective that respond to the two main research questions. The first objective of the work identifies if the selected companies in the PSE are undervalued, overvalued or properly valued. The second objective identifies the factors that influence stock prices in the PSE to deviate from their intrinsic value. The second objective is accomplished from the previous works done by the other scholars.

The company growth rate is the only parameter that is simulated to obtain randomly generated growth rates. Monte Carlo Simulation was used to generate growth rate with a Percentage Point Function (PPF). To generate growth rate with the PPF, the following parameters were used: $\mathrm{x}$-randomly generated number, such as $0<\mathrm{x}<1$, 


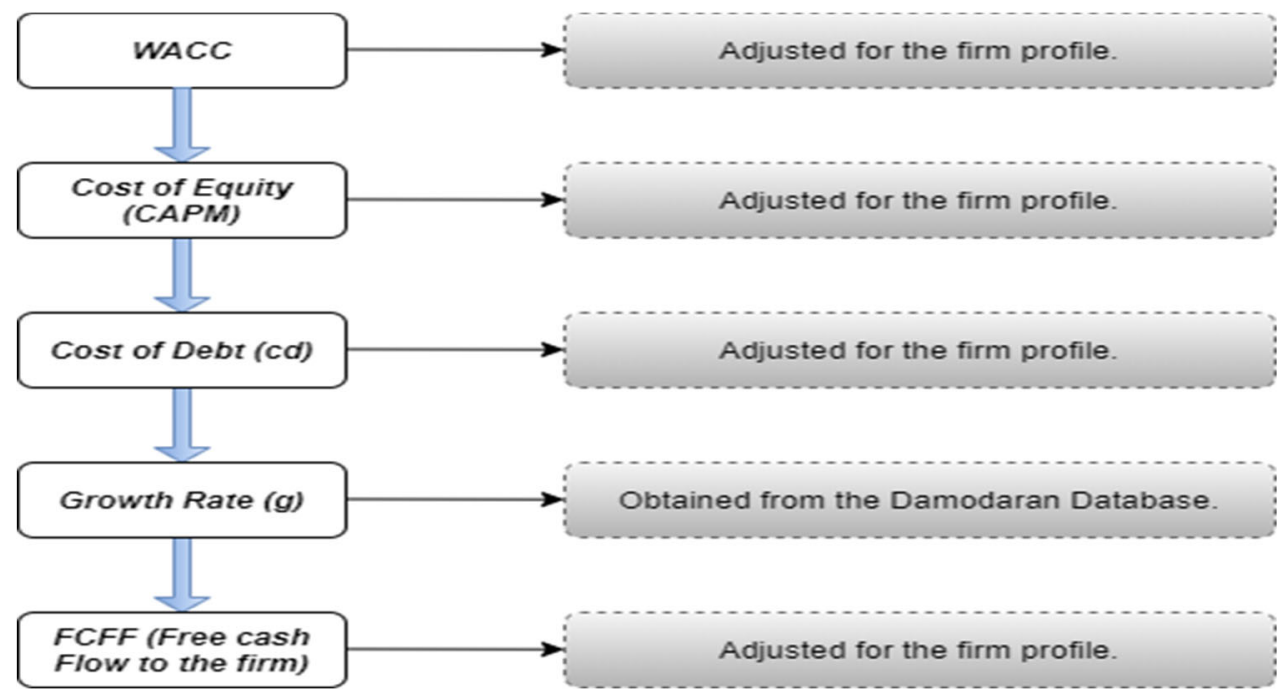

1: Parameters used for estimating intrinsic value of the listed companies in the PSE Source: Authors own elaboration based on the WACC model

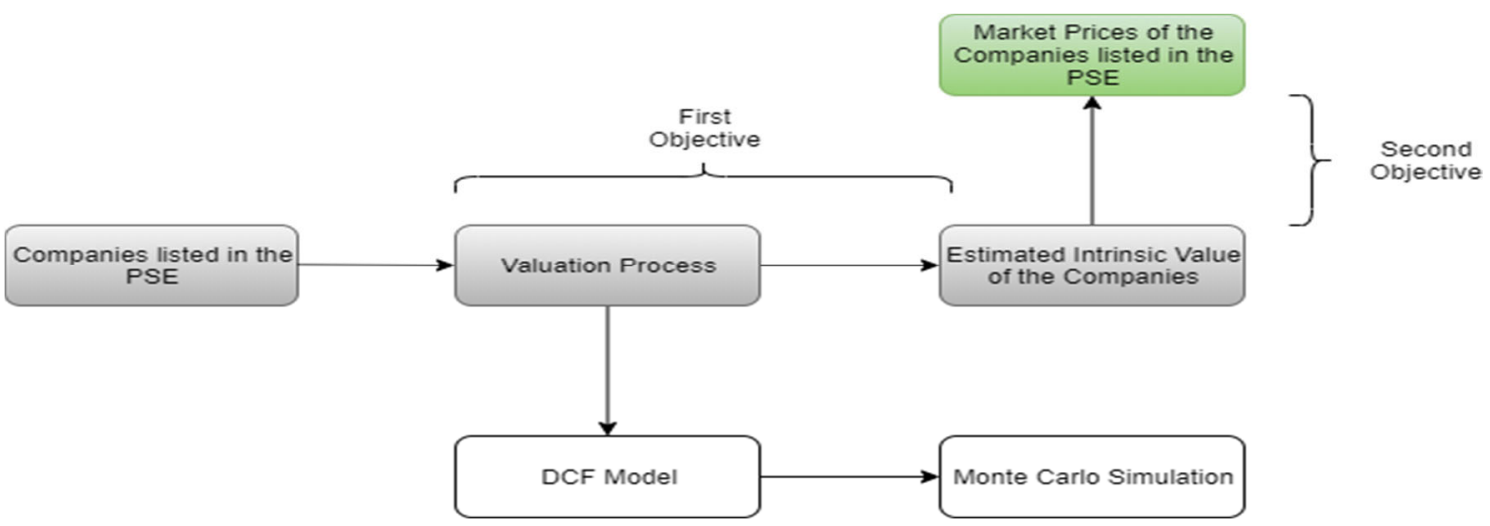

2: Schematic process of the research work

Source: Authors own elaboration

growth rate based on the Domodaran Database, a standard deviation of growth rate. The number of randomly generated growth rates equals the number of simulated years. Each simulation trial contains its own randomly generated growth rates. Standing on the number of samples, the trials were repeated within identical conditions and independent from each other. PPF stands for the $\mathrm{x}$ value on the cumulative distribution function, such as:

$P(X>=x)=p$,

where $p$ is the randomly generated number.

The inputs below define the experiment used on the Monte Carlo Simulation, such as average Free Cash Flow to the Firm (known as CF), growth rate represented in decimal (g), standard deviation of growth rate, discount rate obtained from the weighted average cost of capital (r), number of years to simulate and number of trials. The simulation process starts with randomly generated growth rates for a specific number of years. The second phase continues by calculating cumulative DCF-s. Cumulative DCF-s stops adding new values if the difference within two consecutive DCF-s is less than 6\%. Cumulative DCF-s might be less than the number of years specified in the program. Moreover, each selected firm has been simulated with three different trials (samples), such as 500, 1000 and 10000. Plots indicate the normal distribution of the cumulative DCF-s.

1. The following programs were used to generate the results: Programming Language (Python 3.5.3)

2. Development Environment (Jupyter Notebook)

3. Random Number Generator (used "np.random. rand” method from Pandas library, ver: 0.24.1)

4. Generating Random Growth Rate (as 'g') is used "norm.ppf" function from "scipy.stats" library, ver: 1.2.1

5. Cumulative DCF and Normal Distribution plots are used: pyplot functions from Matplotlib Library, ver: 3.0.2.

(The program concerning the implementation of the formula is available on request). 
I: Represents book value per share, estimated DCF per share and average market price of the Czech listed companies

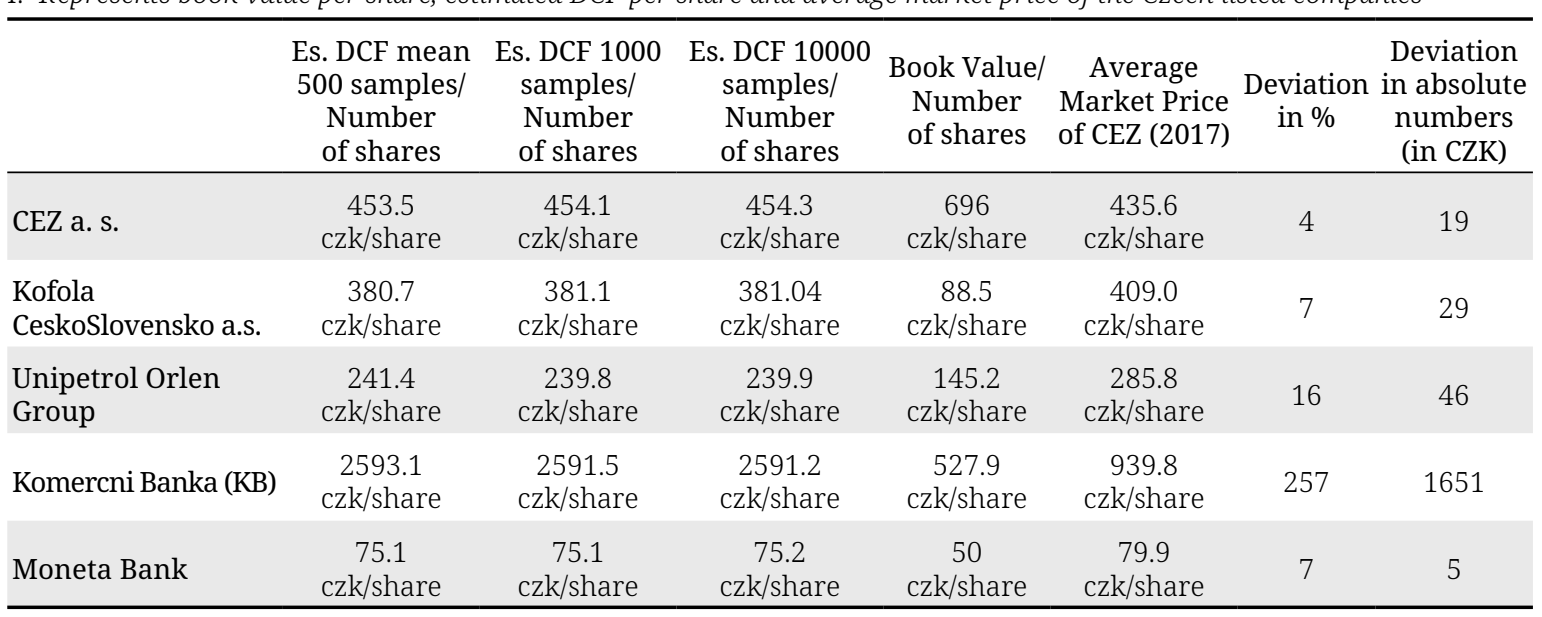

Source: Authors own elaborations based on the audited financial statements of the companies listed in the PSE

II: Indicates book value per share, estimated DCF per share and average market price of the international listed companies

\begin{tabular}{|c|c|c|c|c|c|c|c|}
\hline & $\begin{array}{c}\text { Es. DCF mean } \\
500 \text { samples/ } \\
\text { Number } \\
\text { of shares }\end{array}$ & $\begin{array}{c}\text { Es. DCF } 1000 \\
\text { samples/ } \\
\text { Number } \\
\text { of shares }\end{array}$ & $\begin{array}{c}\text { Es. DCF } 10000 \\
\text { samples/ } \\
\text { Number } \\
\text { of shares }\end{array}$ & $\begin{array}{l}\text { Book Value/ } \\
\text { Number } \\
\text { of shares }\end{array}$ & $\begin{array}{c}\text { Average } \\
\text { Market Price } \\
\text { of CEZ (2017) }\end{array}$ & $\begin{array}{l}\text { Deviation } \\
\text { in } \%\end{array}$ & $\begin{array}{l}\text { Deviation } \\
\text { in absolute } \\
\text { numbers } \\
\text { (in CZK) }\end{array}$ \\
\hline $\begin{array}{l}\text { Stock Spirit Group } \\
\text { PLC }\end{array}$ & $\begin{array}{c}39.3 \\
\text { czk/share }\end{array}$ & $\begin{array}{c}39.4 \\
\text { czk/share }\end{array}$ & $\begin{array}{c}39.2 \\
\text { czk/share }\end{array}$ & $\begin{array}{c}1.77 \\
\text { czk/share }\end{array}$ & $\begin{array}{c}61.4 \\
\text { czk/share }\end{array}$ & 43 & 22 \\
\hline Erste Group Bank & $\begin{array}{c}3175.7 \\
\text { czk/share }\end{array}$ & $\begin{array}{c}3178.5 \\
\text { czk/share }\end{array}$ & $\begin{array}{c}\text { 3,178.9 } \\
\text { czk/share }\end{array}$ & $\begin{array}{c}1084.33 \\
\text { czk/share }\end{array}$ & $\begin{array}{c}1,084 \\
\text { czk/share }\end{array}$ & 360 & 2,297 \\
\hline $\mathrm{O} 2$ & $\begin{array}{c}1089.4 \\
\text { czk/share }\end{array}$ & $\begin{array}{c}1089 \\
\text { czk/share }\end{array}$ & $\begin{array}{c}1,088.1 \\
\text { czk/share }\end{array}$ & $\begin{array}{c}51 \\
\text { czk/share }\end{array}$ & $\begin{array}{c}270 \\
\text { czk/share }\end{array}$ & 400 & 819 \\
\hline $\begin{array}{l}\text { Vienna Insurance } \\
\text { Group (VIG) }\end{array}$ & $\begin{array}{c}416.6 \\
\text { czk/share }\end{array}$ & $\begin{array}{c}416.9 \\
\text { czk/share }\end{array}$ & $\begin{array}{c}416.6 \\
\text { czk/share }\end{array}$ & $\begin{array}{c}120.3 \\
\text { czk/share }\end{array}$ & $\begin{array}{c}641.2 \\
\text { czk/share }\end{array}$ & 54 & 224 \\
\hline Phillip Morris CR & $\begin{array}{c}2276.7 \\
\text { czk/share }\end{array}$ & $\begin{array}{c}2284.7 \\
\text { czk/share }\end{array}$ & $\begin{array}{c}2,276 \\
\text { czk/share }\end{array}$ & - & $\begin{array}{c}14,830 \\
\text { czk/share }\end{array}$ & 650 & 12,554 \\
\hline
\end{tabular}

Source: Authors own elaborations based on the audited financial statements of the companies listed in the PSE

\section{RESULTS}

The study measures the estimated intrinsic value of the 10 selected companies listed in the PSE. Companies were evaluated independently with identical valuation methods (DCF model). Tab. I indicates deviation within market prices and estimated intrinsic value of the Czech listed companies in the PSE. The average deviation between market prices and intrinsic value of the Czech listed companies was $58.17 \%$ or in the absolute numbers 350 CZK. The listed firm that holds the lowest deviation between market prices and intrinsic value was Moneta Banks with only 5 CZK (7\%), followed by CEZ a. s. with 19 CZK (4\%), Unipetrol Orlen Group with 46 CZK (16\%) and Komercni Banks with 1651 CZK (257\%). Tab. III in the appendix show weighted average cost of capital for selected companies from 2013 till 2017. Tab. IV represents beta coefficient calculated from the regressing stock returns of the individual companies with PSE returns, from 2013 till 2014. Beta coefficient is an important risk component in determining discount rate where higher beta reflect lower firm value and the other way around. The highest beta was imposed on Erste Group Bank ( $\beta=1.93$ ) and the lowest on the Kofola CeskoSlovensko ( $\beta=-0.1$ ). Erste Group Bank is 1.9 times riskier than PSE index while Kofola CeskoSlovensko moves in the opposite direction to the PSE.

Tab. II shows deviation within estimated intrinsic value and market prices of the international companies listed in the PSE. Results indicate that the average deviation within average market prices and estimated intrinsic value of the international listed companies till 2017 was 301\% or 3183 CZK. International companies were deviating 5.2 times more than Czech listed companies. The international firm with the lowest deviation was Stock Spirit PLC with 22 CZK (43\%), followed by Vienna Insurance Group with 224 CZK (54\%), O2 with 819 CZK (400\%), Erste Group 2297 CZK (360\%) and Philip Morris CR with 12554 CZK (650\%). 


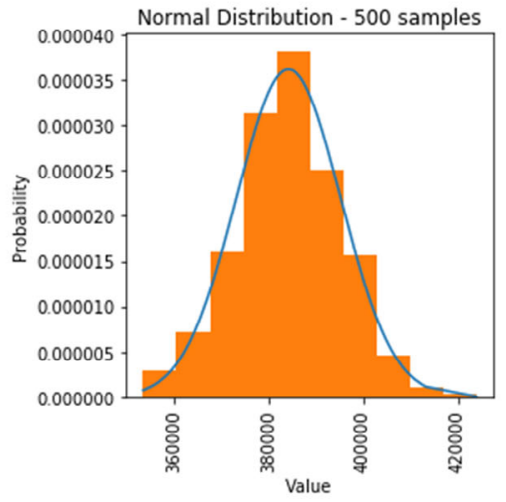

STD: 11029.5 , Mean: 384147.9

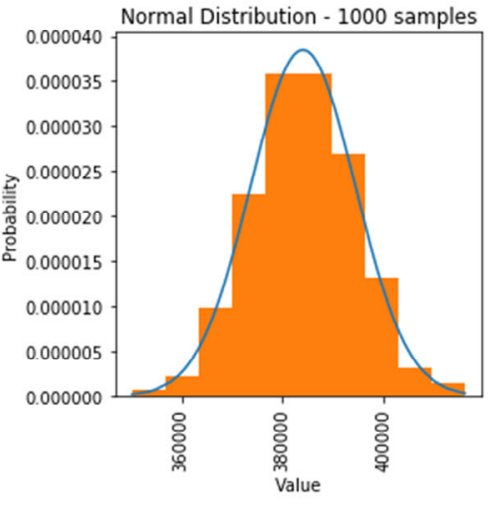

STD: 10365.8 , Mean: 384021.4

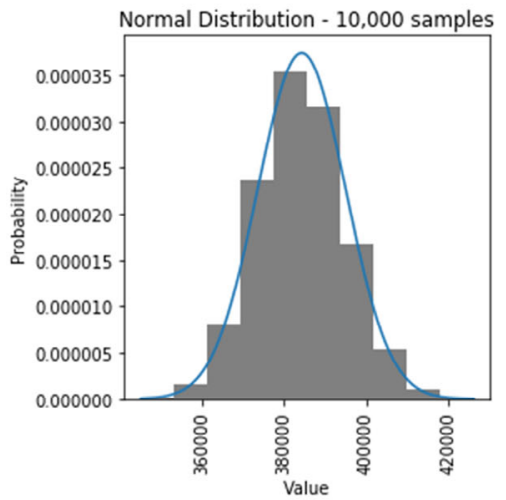

STD: 10668.5 , Mean: 384264.0

3: Normal distribution for the Moneta Bank with 500, 1000 and 10000 samples

Source: Authors own elaborations based on the audited financial statements of the Moneta Bank (MB, 2018)
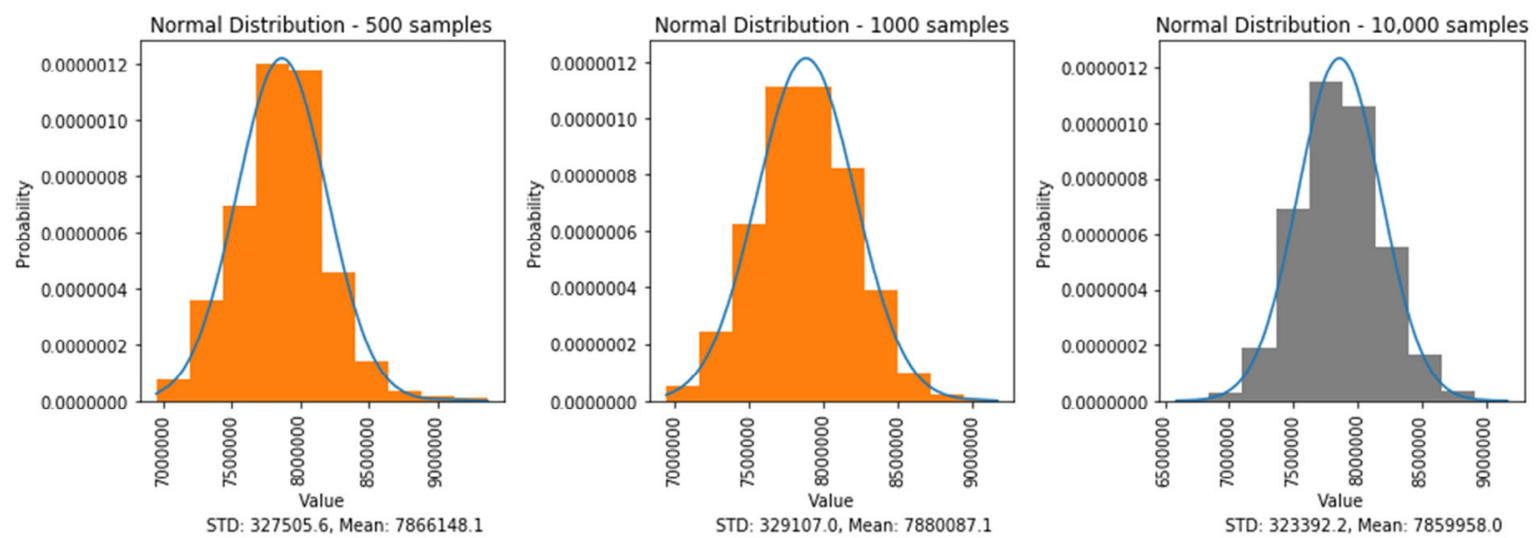

4: Normal distribution for the Stock Spirit Group PLC with 500,1000 and 10000 samples

Source: Authors own elaborations based on the audited financial statements of the Stock Spirit Group PLC (PLC, 2018)

The deviation among average market prices and their estimated intrinsic value of the companies listed in the PSE was 179.82\% (1766 CZK). The overvalued companies till 2017, were such as Kofola CeskoSlovensko, Unipetrol Orlen Group, Moneta Bank, Stock Spirit, Phillip Morris and Vienna Insurance Group. In contrast, the companies that were undervalued till 2017 were CEZ, Komercni Banka, Unipetrol Orlen Group and O2.

Fig. 3 shows the normal distribution of the Moneta Bank (MB) with 500, 1000 and 10000 trials. Moneta Bank (MB) stands as the company with the lowest deviation between market price and intrinsic value. The cumulative DCF-s within normal distribution stand within the range of 38 billion CZK. Moreover, MB stock prices are considered the closest to the equilibrium level from the Czech listed companies.
Fig. 4 indicates a normal distribution of the Stock Spirit Group PLC with 500, 1000 and 10000 trails. Market prices of the Stock Spirit Group are considered the closest to the equilibrium level from the international listed companies.

Verification of the first research question (Q1): Market prices of the companies listed in the PSE deviate from their estimated equilibrium (intrinsic value) in the range of $180 \%$. In addition, Czech listed companies are closer to their equilibrium than international one.

Verification of the second research question (Q2): Factors deviating stock prices in the PSE identified from the previous scholars, stand as follows: GDP, Inflation, exchange rate and unemployment.

\section{CONCLUSION}

Stock markets play a crucial role in channelizing the unutilized funds when the stock prices reflect the fundamentals of the economy. Efficient stock prices boost market confidence and provide accurate signals for financial investors. Stock markets of eastern European countries hold an insignificant number of listed companies and characterized by inefficiency levels. In addition, inefficiency indicates that stock price in these countries stands beyond economic reality and intrinsic values of 
the companies. The study investigates the deviation of the stock prices from their intrinsic value of the selected companies in the PSE. Moreover, our study employee valuation techniques to measure the estimated intrinsic value of the companies. The results of the study inform stakeholders if the listed stocks in the PSE are correctly priced. Outcomes of the work reveal if the listed companies were undervalued, overvalued or properly valued until 2017. Standing on the obtained results, Czech listed companies were closer to the estimated intrinsic value (equilibrium price) than international companies. The average deviation between market prices and the intrinsic value of the Czech listed companies was 58\%. In contrast, international companies were deviating from their intrinsic value in the range of 301\%. The average deviation of the 10 listed companies in the PSE was 180\%. The lowest deviation from the Czech listed companies appeared on the Moneta Bank, with only 6.5\%. However, from the international one, the lowest deviation stands for the Stock Spirit PLC with 43.3\%. The results of the work show that stock prices in the PSE contain speculative elements and do not reflect intrinsic value of the firms. The authors of the study cannot recognize the equilibrium price since no threshold identifies the deviation tolerance between market prices and intrinsic value. Future research might identify the deviation of the market prices from the intrinsic value on the entire eastern European countries. Factors that deviate stock prices of the companies listed in the PSE from their estimated intrinsic value are diverse. The answer to the second research questions was generated from the literature review studied from the previous scholars. Firm-specific factors such as liquidity ratios, profitability indicators, and turnover levels are important factors that influence stock price movements. To the best knowledge, there are not enough studies to confirm the importance of the firm-specific factors on the price movements of the companies listed in the PSE. For this purpose, the work is primarily focused on collecting information's on the macroeconomic indicators that influence price changes in the PSE. Macroeconomic indicators that influence stock prices in the PSE, are such as GDP, Inflation, exchange rate and unemployment. Western stock markets hold solely short-run effect on the PSE stock prices while no long-run effect is detected. Some of the companies in the PSE are listed also in the other stock exchanges which might be an important factor why stock prices of the international companies deviate in the larger scale from the intrinsic value compared to the national companies. For this purpose, additional studies are required to investigate the extent to which demand for the stocks on the other stock exchanges might influence stock prices of the international companies listed in the PSE to deviate from their intrinsic value.

The methods used for the study do not consider possible bankruptcies and companies' lifespan. Moreover, the study does not consider probable mergers, acquisitions and future profitable projects. Legal and financial due diligence provides a broader outlook on the risk that the companies are exposed which stand as additional limitation of the work. Moreover, the study used only the DCF model with FCFF input while other techniques such as asset-based method, free cash flow to equity method, dividend-based method, and market multiples ratios might provide other results. Future studies might identify in the long-run, differences that various techniques impose on the company value outcomes. DCF model can provide partial explanations to the price changes in the PSE, since various factors influence stock price movements. Standard finance theories show that stock prices are generally influenced by the internal performance of the firms and from national and international macroeconomic environment. Since the DCF model is incapable to completely describe price changes, more sophisticated models are required to explain the complex reality of the stock price movements.

\section{REFERENCES}

CEZ GROUP. 2018. Annual Reports. CEZ Group. [Online]. https://www.cez.cz/en/investors/financialreports/annual-reports [Accessed: 2020, June 15].

CZECH NATIONAL BANK. 2018. Annual Report 2018. Available at: https://www.cnb.cz/export/sites/cnb/ en/about_cnb/.galleries/performance/annual_reports/download/vz_2018_en.pdf [Accessed: 2020, July 15].

DAMODARAN, A. 2012. Investment valuation: Tools and techniques for determining the value of any asset. Vol. 666. $3^{\text {rd }}$ Edition. John Wiley \& Sons.

DAMODARAN, A. 2018. Data: Archives. Growth rate estimation. Darmodaran Online. [Online]. Available at: http://pages.stern.nyu.edu/ adamodar/ [Accessed: 2020, June 15].

DOW JONES. 2018. Kofola CeskoSlovensko a. s. The Wall Street Journal. Available at: https://www.wsj. com/market-data/quotes/CZ/XPRA/KOFOL/financials/annual/cash-flow [Accessed: 2020, June 15].

DRAGOTĂ, V. and TुILICĂ, E. 2014. Market efficiency of the Post-Communist East European stock markets. Central European Journal of Operations Research, 22(2): 307-337.

ERSTE GROUP BANK. 2018. Financial Reports. Erste Group. [Online]. Available at: https://www. erstegroup.com/en/investors/reports/financial-reports [Accessed: 2020, June 15]. 
FAMA, E. F. 1976. Efficient capital markets: reply. The Journal of Finance, 31(1): 143-145.

GILMORE, C. G. and MCMANUS, G. M. 2002. International portfolio diversification: US and Central European equity markets. Emerging Markets Review, 3(1): 69-83.

GRAMBOVAS, C. A. 2003. Exchange rate volatility and equity markets. Eastern European Economics, 41(5): 24-48.

GUIDI, F., GUPTA, R. and MAHESHWARI, S. 2011. Weak-form market efficiency and calendar anomalies for Eastern Europe equity markets. Journal of Emerging Market Finance, 10(3): 337-389.

HANOUSEK, J. and FILER, R. K. 2000. The relationship between economic factors and equity markets in Central Europe. Economics of transition, 8(3): 623-638.

HANOUSEK, J. and NOVOTNY, J. 2013. Price jump behavior during financial distress: intuition, analysis and a regulatory perspective. In: AROURI, M., BOUBAKER, S. and NGUYEN, D. K. Emerging Markets and the Global Economy: A Handbook. New York: Academic Press, Elsevier. Forthcoming.

HOROBET, A. and DUMITRESCU, S. 2009. On the causal relationships between monetary, financial and real macroeconomic variables: evidence from Central and Eastern Europe. Economic Computation \& Economic Cybernetics Studies \& Research, 43(3): 77-94.

KULHÁNEK, L. 2012. The relationship between stock markets and gross domestic product in the Central and Eastern Europe. In: Proceedings Of The $7^{\text {th }}$ International Conference On Currency, Banking And International Finance-How Does Central And Eastern Europe Cope Up With The Global Financial Crisis? Vil. 1. Bratislava: Ekonóm, University of Economics in Bratislava, pp. 135-145.

MALKIEL, B. G. and FAMA, E. F. 1970. Efficient capital markets: A review of theory and empirical work. The journal of Finance, 25(2): 383-417.

MOORE, T. and WANG, P. 2007. Volatility in stock returns for new EU member states: Markov regime switching model. International Review of Financial Analysis, 16(3): 282-292.

O2. 2018. Annual and Half-Year Reports. O2. [Online]. Available at: https://www.o2.cz/spolecnost/en/ annual-and-half-year-reports/ [Accessed: 2020, June 15].

PHILLIP MORRIS. 2018. Audited Financial Statements. Phillip Morris Czech Republic. [Online]. Available at: https://www.pmi.com/markets/czech-republic/en/investor-relations/shareholderinformation-archives [Accessed: 2020, June 15].

PRAGUE STOCK EXCHANGE. 2017. Prague Stock Exvhange - About Us. Prague Stock Exchange. [Online]. Available at: https://www.pse.cz/en/about-us [Accessed: 2020, July 15].

PRAŽÁK, T. and STAVÁREK, D. 2017. The relationship between stock market development and macroeconomic fundamentals in the Visegrad group. Comparative Economic Research, 20(3): 5-23.

SAMITAS, A. and KENOURGIOS, D. 2007. Macroeconomic factors' influence on 'new' European countries' stock returns: the case of four transition economies. International Journal of Financial Services Management, 2(1/2): 34-49.

SCHEICHER, M. 2001. The comovements of stock markets in Hungary, Poland and the Czech Republic. International Journal of Finance \& Economics, 6(1): 27-39.

SHILLER, R. C. 2000. Irrational exuberance. Philosophy and Public Policy Quarterly, 20(1): 18-23.

STOCK SPIRIT GROUP PLC-SSG. 2017. Annual Financial Statements. Stock Spirit Group. [Online]. Available at: https://www.stockspirits.com/investors/key_financial_statements/consolidated_income_ statement.aspx [Accessed: 2020, June 15].

STOICA, O. and DIACONASU, D. E. 2011. An Examination of the Calendar Anomalies on Emerging Central and Eastern European Stock Markets. In: $3^{\text {rd }}$ World Multiconference on Applied Economics, Business and Development. Recent Researches in Applied Economics. Iasi, Romania.

STOICA, O., NUCU, A. E. and DIACONASU, D. E. 2014. Interest rates and stock prices: evidence from Central and Eastern European Markets. Emerging Markets Finance and Trade, 50(sup4): 47-62.

UNIPETROL ORLEN GROUP. 2018. Annual and half-year reports. Unipetrol. [Online]. Available at: http://www.unipetrol.cz/en/InvestorRelations/AnnualandSemi-annualReports/Pages/2017.aspx [Accessed: 2020, July 15].

VIENNA INSURANCE GROUP-VIG. 2018. Annual Financial Statements. Vienna Insurance Group-VIG [Online]. Available at: https://www.vig.com/en/investor-relations/downloads/annual-reports.html [Accessed: 2020, July 15].

WOLFF, G. B. 2007. Foreign direct investment in the enlarged EU: do taxes matter and to what extent? Open Economies Review, 18(3): 327-346.

Contact information

Florin Aliu: florin.aliu@ubt-uni.net

Adriana Knapkova: knapkova@utb.cz

Hoang Khang Tran: htran@utb.cz

Bashkim Nurboja: bashkim.nurboja@ubt-uni.net 
APPENDIX

Appendix A: III. Weighted Average Cost of Capital of the 10 companies listed in the PSE, from 2013 till 2017

\begin{tabular}{|c|c|c|c|c|c|}
\hline & 2013 & 2014 & 2015 & 2016 & 2017 \\
\hline CEZ, a.s. & $3.1 \%$ & $2.7 \%$ & $2.4 \%$ & $2.3 \%$ & $2.5 \%$ \\
\hline ČeskoSlovensko & $3.8 \%$ & $2.9 \%$ & $3.0 \%$ & $2.7 \%$ & $3.0 \%$ \\
\hline Stock Spirit Group & $3.3 \%$ & $2.6 \%$ & $2.1 \%$ & $1.9 \%$ & $2.3 \%$ \\
\hline Unipetrol Orlen Group & $1.3 \%$ & $1.1 \%$ & $0.6 \%$ & $0.5 \%$ & $1.2 \%$ \\
\hline Erste Group Bank & $4.5 \%$ & $4.2 \%$ & $3.9 \%$ & $3.4 \%$ & $3.3 \%$ \\
\hline Komercni Banka & $4.4 \%$ & $4.0 \%$ & $3.8 \%$ & $3.4 \%$ & $3.3 \%$ \\
\hline O2 Company & $2.1 \%$ & $1.5 \%$ & $2.0 \%$ & $1.9 \%$ & $2.5 \%$ \\
\hline Vienna Insurance Group (VIG) & $4.4 \%$ & $4.0 \%$ & $3.8 \%$ & $3.3 \%$ & $3.2 \%$ \\
\hline Phillip Morris CR & $4.5 \%$ & $3.7 \%$ & $3.5 \%$ & $3.8 \%$ & $3.2 \%$ \\
\hline Moneta Bank & $3.8 \%$ & $3.2 \%$ & $3.5 \%$ & $3.1 \%$ & $3.2 \%$ \\
\hline
\end{tabular}

Source: Authors own elaborations based on the financial statements of the companies listed in the PSE

Appendix B: IV. Average beta coefficient from 2013 till 2017 of the individual companies listed in the PSE

\begin{tabular}{lc}
\hline & Beta coefficient $(\beta)$ \\
\hline CEZ, a.s. & 0.75 \\
Kofola ČeskoSlovensko & -0.1 \\
Stock Spirit Group & 0.55 \\
Unipetrol Orlen Group & 0.56 \\
Komercni Banka & 1.26 \\
Vienna Insurance Group (VIG) & 0.98 \\
Phillip Morris CR & 0.27 \\
Moneta Bank & 0.76 \\
Erste Group Bank & 1.93 \\
O2 Company & 0.44 \\
\hline
\end{tabular}

Source: Authors own elaborations based on the financial statements of the companies listed in the PSE 